\title{
Evaluation of the physicochemical and bacteriological quality of the Loukkos wetlands complex (Morocco)
}

\author{
Badreddine Fathi ${ }^{1,3^{*}}$, Bouchra Salame ${ }^{2}$, Abdelghani Afilal Tribak ${ }^{1}$, Miriam Wahbi ${ }^{3}$, Mustapha Maâtouk $^{3}$ \\ ${ }^{1}$ Research Team in Marine Environment and Natural Risks, Faculty of Science and Technology in Tangier, Editorial Department, PB 416 \\ Tangier Morocco \\ ${ }^{2}$ Depollution and Major Works Department in the Autonomous agency of distribution of electricity and drinking water of Larache province, \\ Department of production, PB 11, Larache 92000 Morocco \\ ${ }^{3}$ Geo Information and territory Planning Research Team, Faculty of Science and Technology in Tangier, Editorial Department, PB 416 \\ Tangier Morocco
}

\begin{abstract}
The estuary of the Loukkos River is a complex ecosystem where various factors affect the quality of water. Our study is assessing the degree of water pollution in the complex of the lower Loukkos wetland's surface water, which is situated at the river mouth of the Loukkos river in the eastern periphery of Larache city. To realize this objective, we collected water samplings from five area sites during summer period from May to August 2016 to analyse eight parameters physicochemical including dissolved oxygen (DO), temperature, $\mathrm{pH}$, electrical conductivity, turbidity, salinity, suspended matter and nitrates. This study was accompanied by a bacteriological analysis relating to the enumeration of total coliforms and faecal coliforms, intestinal enterococci and reducing anaerobic sulphites. The analysis's results shed lights on factors of contamination and collaborate to the physicochemical evaluation and bacteriologic quality of surface water. The quality indicators spatialization reveals interactions between the various phenomena acting on the functions of this Ramsar site.
\end{abstract}

\section{Introduction}

Wetlands are ecosystems recognized for their beneficial hydrological biogeochemical and ecological functions. Yet, their values have witnessed a major decline in the last four decades $[\underline{1}, 2]$. These rich and fragile ecosystems are and abusive heavily and abusively exploited [3]. The estuarine wetlands' water is constantly polluted by several sources, similar to those in Nahr Ibrahim in Lebanon, which are characterized by nitrate pollution and high levels of bacteriological contamination [4].Also akin to these pollutants are those in Wadi Laou and the Tahdart wetland in Northern Morocco, the waters of which are of poor quality [5]. Our study focused on the lower Loukkos complex located in northern Morocco, classified in the Ramsar Convention since 2004 as a wetland complex of international importance. This complex is located at the mouth of the Loukkos River (Fig.1). On an area of 3600 hectares, it is made up of six wetlands connected to each other [6], whose hydrology is affected by four main factors: the surface waters of the Loukkos river and its tributaries, the R'mel water table and ocean water, irrigation water and drainage water from agricultural land [7]. The lower Loukkos complex water resources are subject to many quantitative and qualitative threats. Several agricultural and agro-industrial units are installed on this site, whose liquid discharges constitute potential sources of pollution $[8,9]$. The vulnerability of surface water to these potential sources of pollution calls into question the quality of these waters as well as the future of this aquatic ecosystem. This paper calls into question the quality of water. Does the waters of this ecosystem meet the requirements of surface water quality standards?

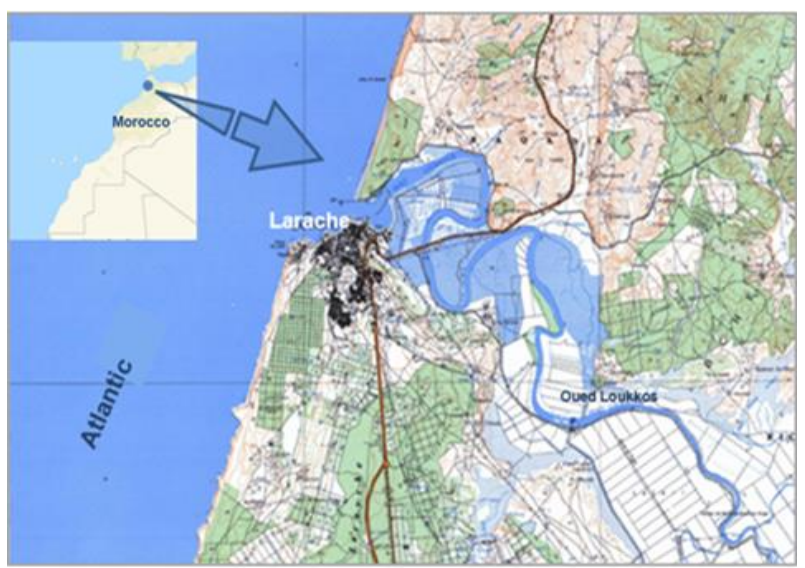

Fig. 1. Location of the study area at the Loukkos River estuary.

The objective of this study is to carry out a physicochemical and bacteriological characterisation of the waters of this complex. The physicochemical study is based on the analysis of certain parameters, namely: (temperature, $\mathrm{pH}$, turbidity, electrical conductivity,

*FATHI Badreddine: badreddine.fathi@etu.uae.ac.ma 
suspended matter, salinity, dissolved oxygen and nitrates). As for the bacteriological study, we have tracked the spatiotemporal evolution of the microbial load (revivable germs at $22^{\circ} \mathrm{C}$ and $37^{\circ} \mathrm{C}$, total coliforms, faecal coliforms, intestinal enterococci and sulphitereducing anaerobes). Sampling period lasted for four months during the summer of 2016.

\section{Materials and methods}

\subsection{Study area}

Two sampling stations A and B have been chosen so that they could be accurately representative surface water characteristics in this wetland. These are located at the discharge point of the main sources of water pollution: rice drain discharges installed on the swamp The Adir and releases the largest agro-industrial unit on the mouth Loukkos (Fig. 2) Sampling campaigns were undertaken during once every month in the period ranging from May and through July 2016, both July 2016 upstream and downstream of these effluents.

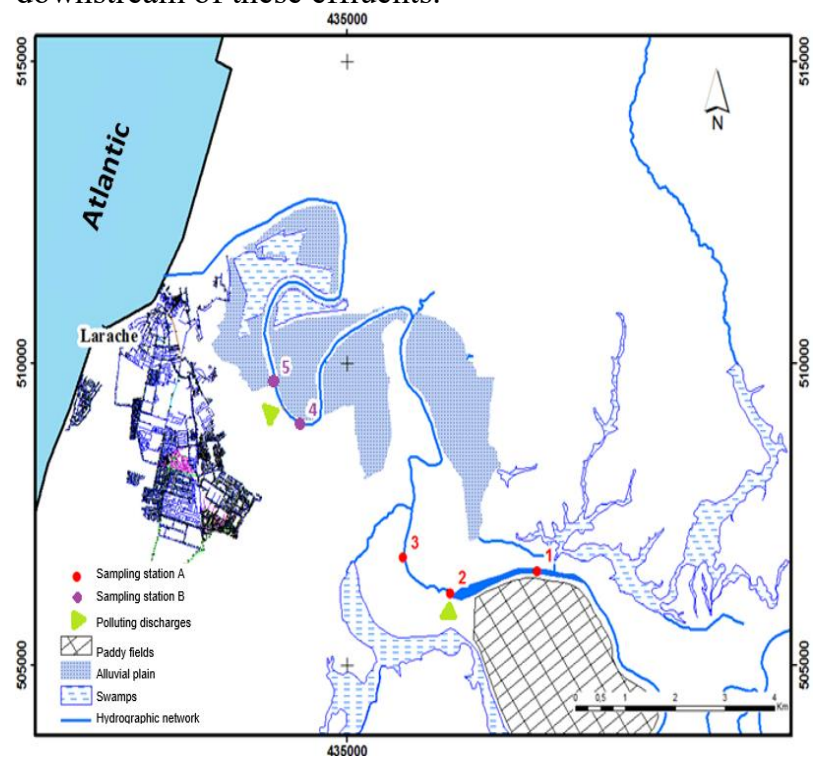

Fig. 2. Location of the different sampling sites.

\subsection{Parameters studied}

The analyses of each parameter was carried out according to standardized methods approved by ONSSA.

\subsubsection{Physicochemical characterization}

The study of the physicochemical quality is based on the analysis of eight parameters according to the following methods: temperature $\left(\mathrm{T}^{\circ}\right)(\mathrm{NM} 03.7 .008,1989)$ and hydrogen potential $(\mathrm{pH})(\mathrm{NM} 03.7 .009,2001)$, the electrical conductivity at $20^{\circ} \mathrm{C}(\mathrm{NM} 03.7 .011,2001)$ were measured in situ, for the turbidity (NM 03.7.010, 1989), the salinity [10] O2 dissolved (NM 03.7.029, 1991), Suspended Matter (SM) (NM 03.7.052, 1996), nitrates (NM 03.7.014, 1990).

\subsubsection{Bacteriological characterization:}

The bacteriological study consisted of the enumeration of: revivable germs at $22 \mathrm{C}^{\circ}$ and at $37 \mathrm{C}^{\circ}$ (NM 03.7.005), total coliforms and faecal coliforms (NM 08.0.175, 2009), intestinal enterococci (AFNOR NF EN ISO 6222, 1999), sulphite-reducing anaerobes (NM 08.0.10).

\subsubsection{Data spatialization:}

The results of the surface water characterization obtained were integrated into GIS for mapping the distribution of the analysed parameters in order to do a spatial treatment and understand the interaction of different phenomena.

\section{Results and discussion}

\subsection{Physicochemical characterization:}

The results of the physicochemical characterization of the waters in both stations at the lower Loukkos zone are shown in Table 2.

Table 2. The following chart shows the average measurements obtained from analyzing surface water samples using different parameters.

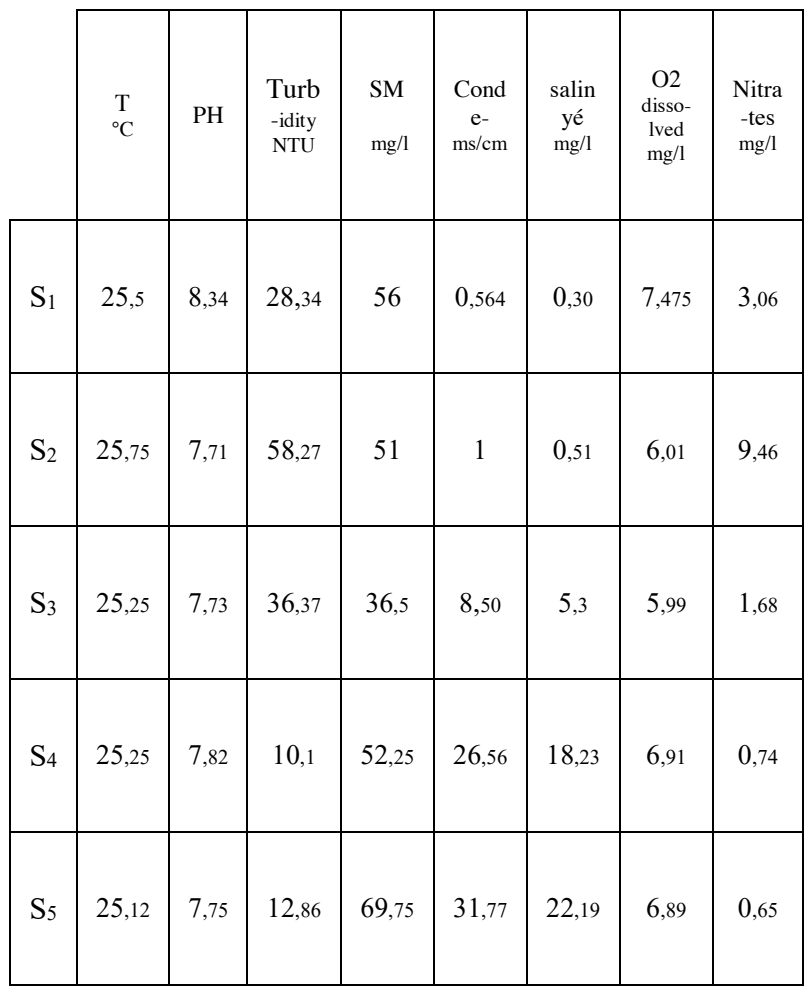

The results obtained helped us to keep track of the spatiotemporal evolution of the quality of the water studied during the summer period.

Temperature and hydrogen potential $(\mathrm{pH})$ :

By acting on chemical balances and gas solubility, on the activity of different metabolites and biochemical reactions. Temperature rates were revealed to major factor influencing water quality [11]. 


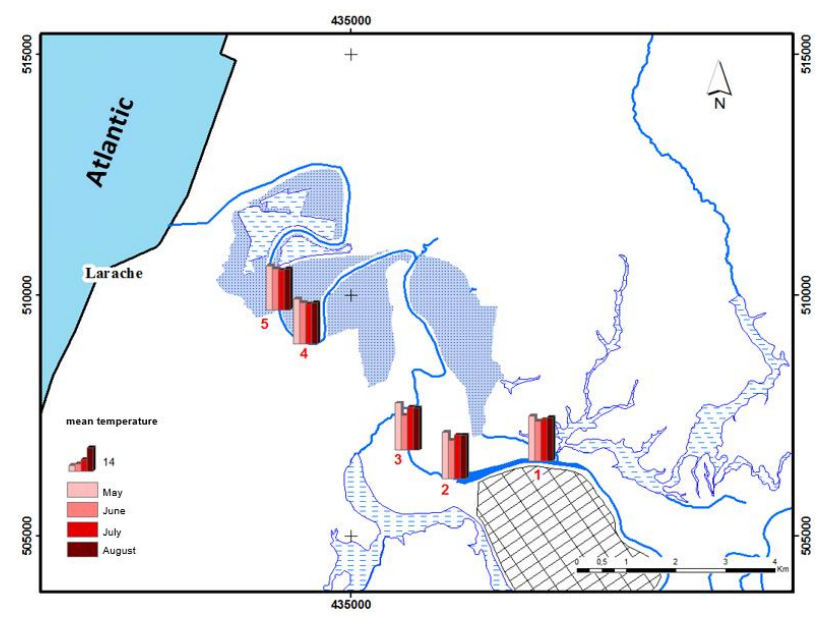

Fig. 3. Distribution of surface water temperature.

The average recorded values between $25^{\circ} \mathrm{C}$ and $26^{\circ} \mathrm{C}$ were generally in accordance with River north in Mohammedia [12].

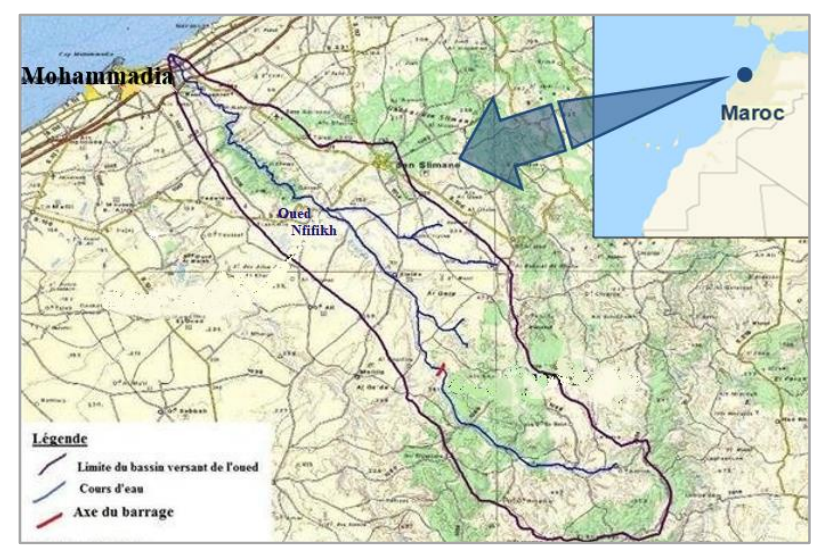

Fig. 4. Location of Nfifikh river [12].

Due to the shallow depths of the water, the variation in temperature can be mainly related to meteorological conditions and tidal oscillations. According to Moroccan standards the water quality in the complex is qualified as being of good to medium quality [13].

The $\mathrm{pH}$ of water supporting aquatic life-fell between 6.5 and 9.0 [14]. The waters studied showed a neutral $\mathrm{pH}$ with an alkaline tendency.

The lowest values were recorded in station S2 of the Adir discharges (7.71 as average), which were probably so due to dissolved carbon dioxide from the metabolic reactions of microorganisms and organic matter contained in this agricultural waste waters [15]. The highest values are-were recorded in station $\mathrm{S} 1$ with a maximum of 8.45 in July. These values are close to those measured by Elmorhit in 2009 [9].

Generally, the $\mathrm{pH}$ of these stations conforms to the Moroccan standard [13] which categorise the waters of the complex as being of good quality.

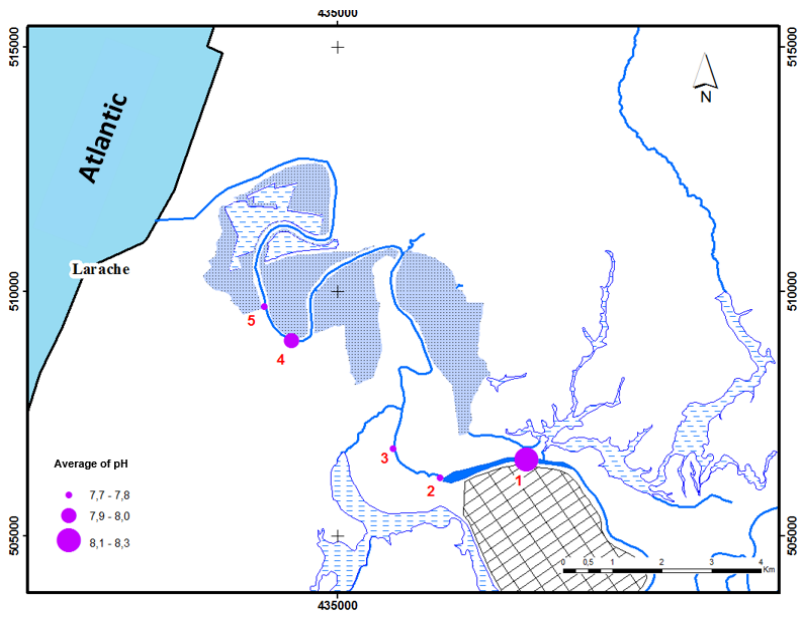

Fig. 5. Distribution of surface water potential of hydrogen $(\mathrm{pH})$.

- Turbidity and suspended matter (SM):

As for turbidity, the values seemed to evolve with a decreasing gradient from upstream to downstream. The highest values were observed in station A with an average of $50 \mathrm{NTU}$ and low values were obtained in station B with an average of 11.4 NTU (Fig. 6). This decreasing evolution could be linked to the phenomenon of flocculation-settling, which is all the more important in the conditions of estuaries [16].

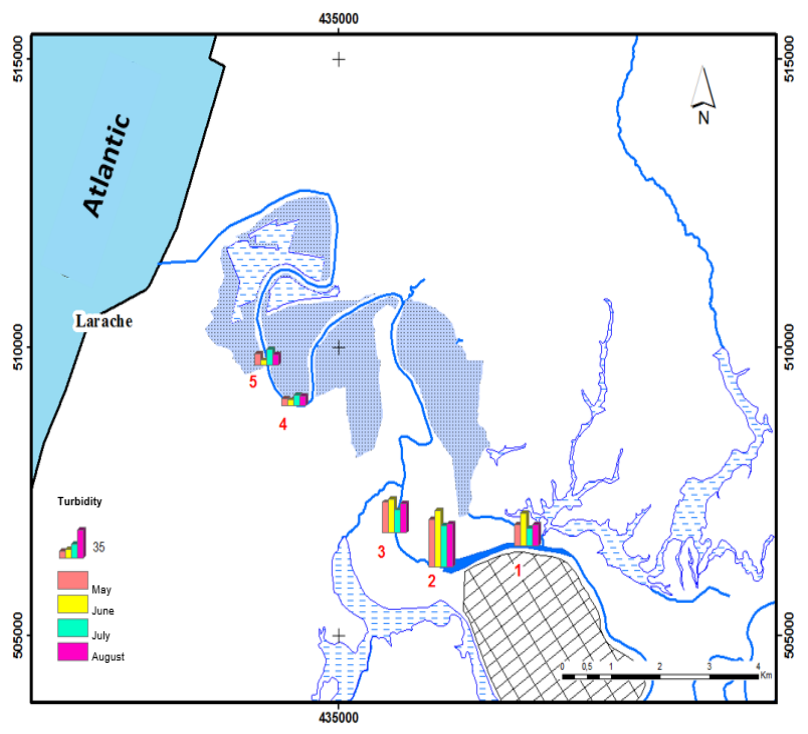

Fig. 6. Distribution of surface water turbidity.

Regarding the Suspended Matter, we note in station A, a decrease in the charge on the upstream side of the guard dam with an average of $56 \mathrm{mg} / 1$ and on the downstream side with an average of $36.5 \mathrm{mg} / 1$. The stagnant water in the reservoir of this dam facilitates the deposition of the SM charge and therefore constitutes a trap for these particles. However, the high levels were observed in station B. The recorded average was $61 \mathrm{mg} / 1$, with an increase in the load downstream (Fig. 7). 


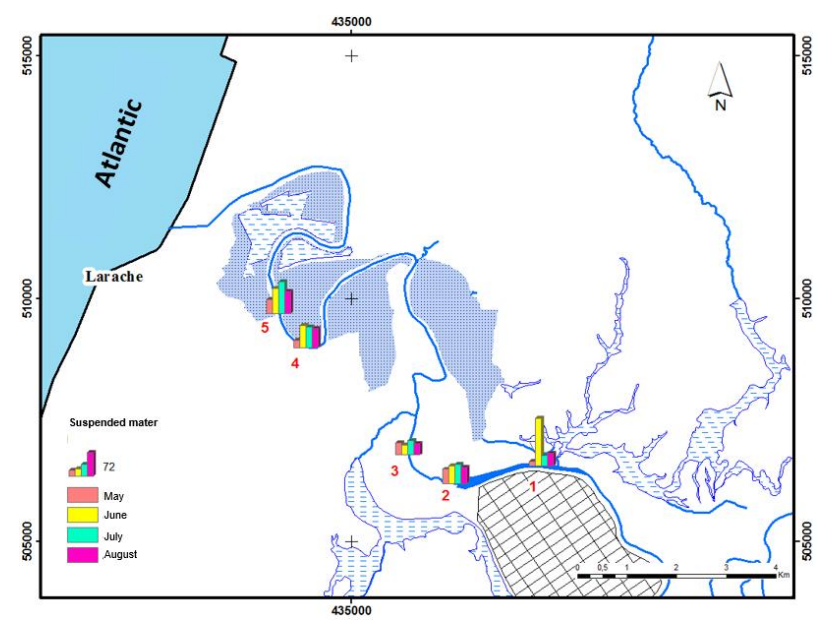

Fig. 7. Distribution of suspended matter in surface water.

This increase in suspended matter in clear water with low turbidity and high salinity appears to be oceanic in origin. The SM fluctuates between $13 \mathrm{mg} / 1$ in May to $143 \mathrm{mg} / 1$ in June and from $22 \mathrm{mg} / 1$ in May and $95 \mathrm{mg} /$ 1 in July in station A and B respectively. The values recorded remain generally lower than those found at Sebou River [17] together with those found at the mouth of Loukkos River averaging $56 \mathrm{mg} / \mathrm{l}$ in the same season [9]. However, the water still in conformity with the Moroccan standard for surface water [13].

- Electrical conductivity and salinity:

The mineralization of the waters was assessed through an analysis of the electrical conductivity. The origin of which is the leaching of rocks from the hydrographic network upstream and the oceanic supply of electrolytes. The electrical conductivity and salinity of the water studied seemed to follow an increasing gradient from upstream to downstream, respectively with a minimum of $0.5 \mathrm{~ms} / \mathrm{cm}$ and $0.3 \mathrm{mg} / 1$ recorded at $\mathrm{S} 1$, and a maximum of $69,75 \mathrm{~ms} / \mathrm{cm}$ and $22.19 \mathrm{mg} / \mathrm{l}$ at S5 (Fig. 8 and Fig. 9). This gradient is undoubtedly due to the influence of saltladen ocean water and to dilution by freshwater upstream.

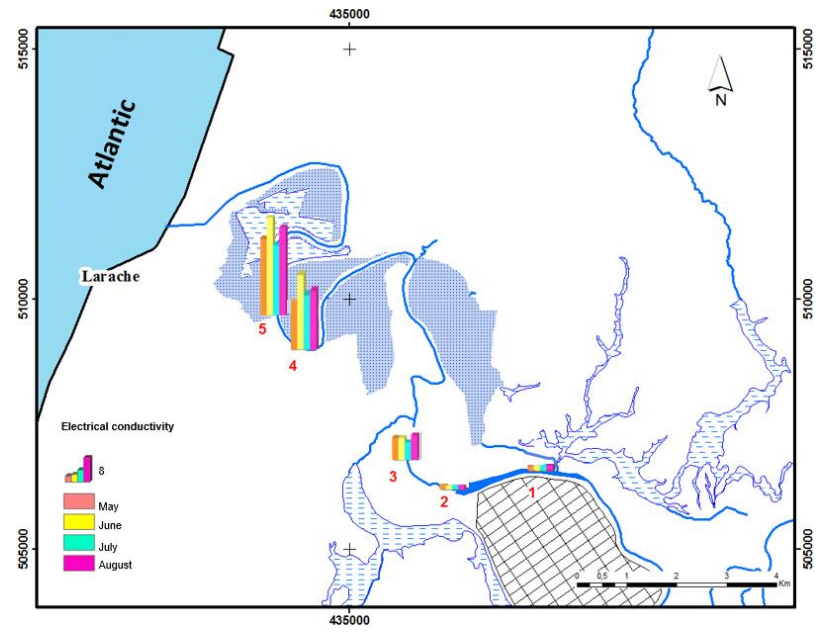

Fig. 8. Distribution of the electrical conductivity of surface water.
Given the recorded values, the Low Loukkos Complex waters are qualified as being of good quality according to the Moroccan standards [13]. The guard dam seems to succeed in playing the role of a shield preventing the progression of mineral salts. These results are in agreement with those found on the same area by Elmorghit in 2009 [9].

- Dissolved oxygen and nitrates:

The rate of dissolved oxygen is almost the same in the two stations, it fluctuates around $6 \mathrm{mg} / \mathrm{l}$ (Fig. 9)-. Yet, it does not reflect the organic matter input from upstream agricultural fields, which is usually the cause of oxygen consumption. A many factors contribute to this high rateone factor is the existence of an oxygenation device downstream of the guard dam. Also relevant is the deposition and trapping of organic matter at the stream bed in station A [18], together with the merging of fresh water with more oxygenated marine water in station B. Globally, lower Loukkos waters are well oxygenated and the oxygen concentrations are within the limits of the Moroccan standard [13].

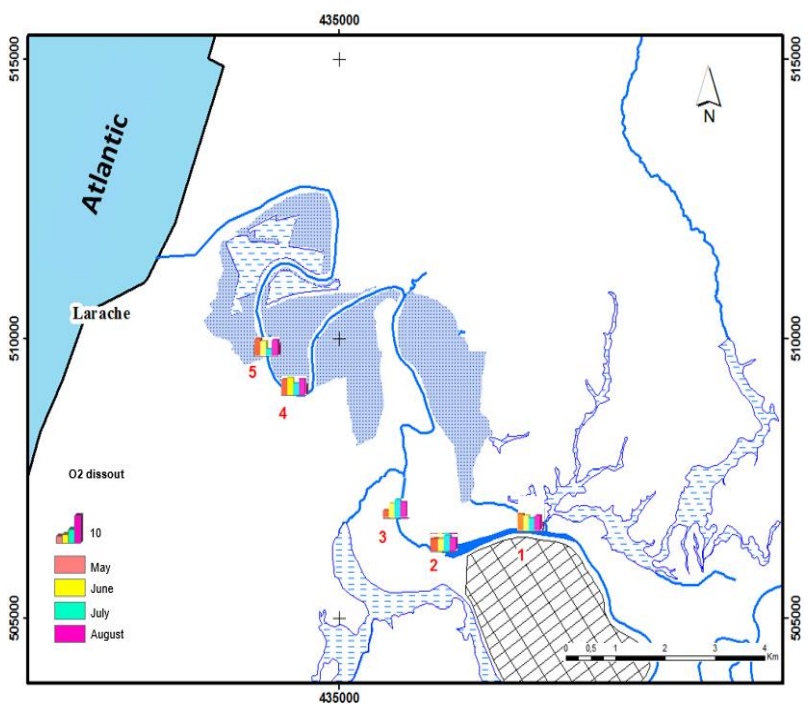

Fig. 9. Distribution of the dissolved oxygen of surface water.

A fairly high rate of nitrates was recorded in station A with a maximum of $9.46 \mathrm{mg} / \mathrm{l}$ in $\mathrm{S} 2$, so close to the rejections of the rice fields. In comparison, low concentrations were recorded in station $\mathrm{B}$ with a maximum of $0.74 \mathrm{mg} / \mathrm{l}$ in station S4 (Fig. 10). The difference between the two stations could be explained by the proximity of station A to agricultural fields and the intense use of fertilizers, which are rich in nitrogenous matter. The low nitrogen load can be linked to dilution and to the phenomenon of denitrification, even if the effluents from agricultural activity are loaded with nitrates. These results are compliant with the work of Verhoeven et al. [19] which claims that wetlands play an important role in water purification. The contents remain lower than 45 to $50 \mathrm{mg} / 1$ admissible values with Moroccan standards [13]. 


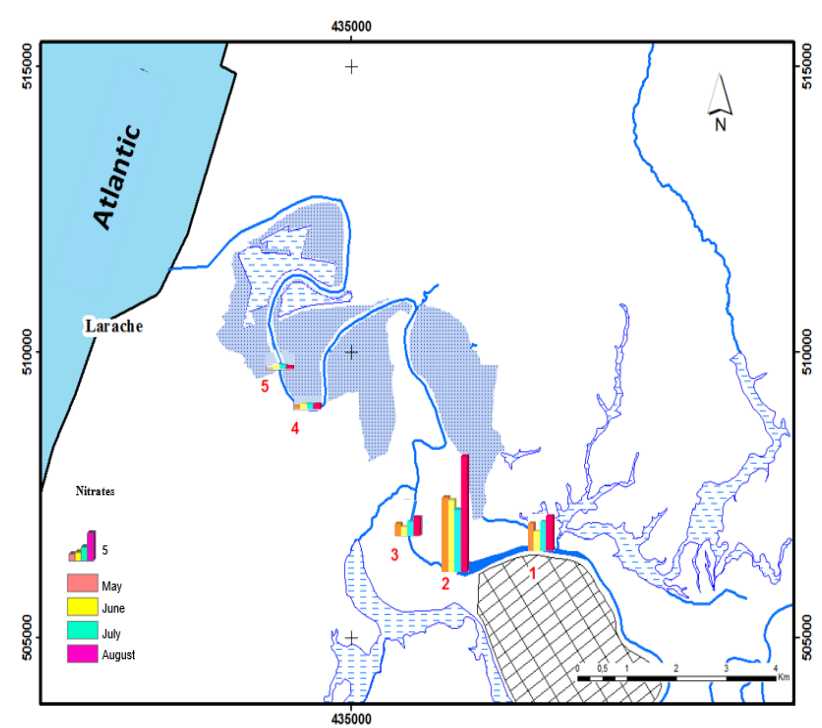

Fig. 10. Distribution of the nitrates of surface water in the study area.

\subsection{Bacteriological characterization:}

The water charge with revivable germs at $22^{\circ} \mathrm{C}$ and $37^{\circ} \mathrm{C}$ was quite high at the sites $\mathrm{S} 1, \mathrm{~S} 2$ and $\mathrm{S} 3$ during the study period, with an average of $810^{3} \mathrm{CFU} / \mathrm{ml} ; 9.210^{3} \mathrm{CFU} / \mathrm{ml}$ and $7.9103 \mathrm{CFU} / \mathrm{ml}$ respectively for germs at $22^{\circ} \mathrm{C}$. And $1.10^{3} \mathrm{CFU} / \mathrm{ml} ; 1.7 .10^{3} \mathrm{UFC} / \mathrm{ml}$ and $1.710^{3} \mathrm{UFC} / \mathrm{ml}$ for GT at $37^{\circ} \mathrm{C}$ in the same sites. As for the sites S4 and S5 the content of revivable germs at $22^{\circ} \mathrm{C}$ did not exceed 2 $10^{3} \mathrm{CFU} / \mathrm{ml}$, whereas for revivable germs at $37^{\circ} \mathrm{C}$ the average values were respectively of the order of $3.110^{2}$ $\mathrm{CFU} / \mathrm{ml}$ and $1.810^{2} \mathrm{CFU} / \mathrm{ml}$ for both sites (Fig. 11 and 12).

The results recorded in sites $\mathrm{S} 1$ and $\mathrm{S} 2$ could be explained by the contribution of contaminated drainage water and the water properties supporting aquatic life in this environment. Furthermore, these sites represent a grazing area favourable to microbial proliferation. Concerning S4 and S5 sites, the low bacterial charge may be linked to the dilution effects by ocean water.

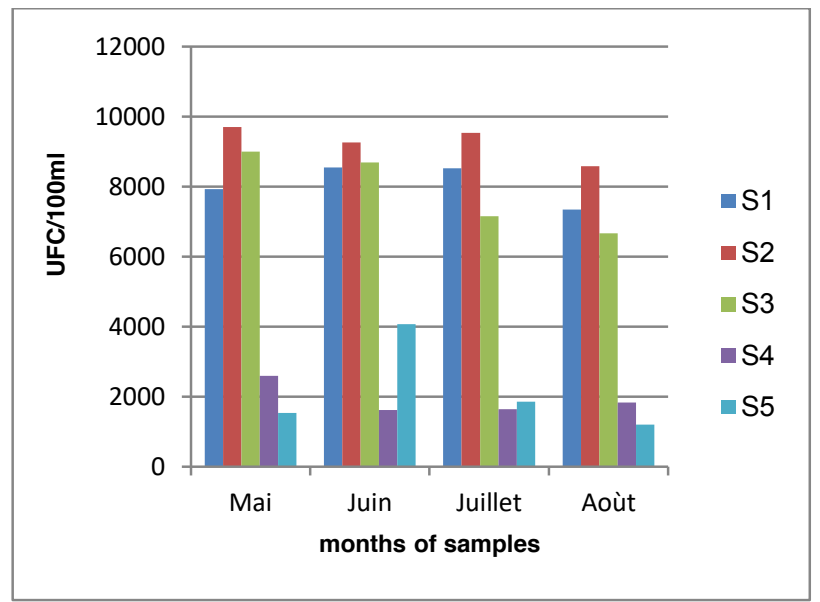

Fig. 11. Spatiotemporal evolution of revivable germs at $22^{\circ} \mathrm{C}$.

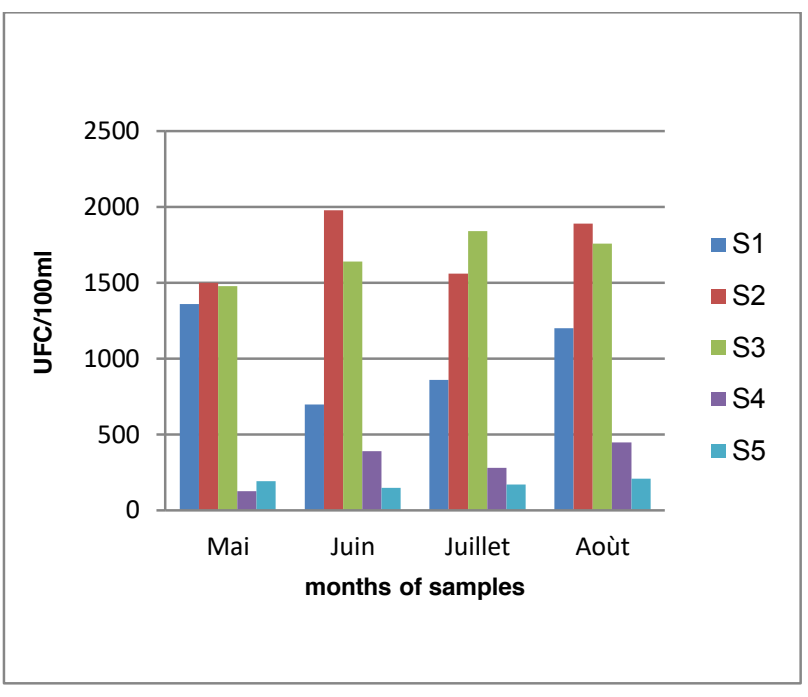

Fig. 12. Spatiotemporal evolution of revivable germs at $37^{\circ} \mathrm{C}$.

The spatiotemporal evolution of total coliforms and faecal coliforms in the studied stations follows almost the same pattern. During the study period, the high charges were recorded in the S2 and S3 sites with an average of: $510 \mathrm{CT} / 100 \mathrm{ml}, 722 \mathrm{CT} / 100 \mathrm{ml}$ and $461 \mathrm{FC} / 100 \mathrm{ml}$, $\mathrm{FC} / 100 \mathrm{ml}$ respectively. The low charges are observed in S4 and S5 sites, the average was: $270 \mathrm{CT} / 100 \mathrm{ml}, 121$ $\mathrm{CT} / 100 \mathrm{ml}$ and $38 \mathrm{FC} / 100 \mathrm{ml}, 126 \mathrm{FC} / 100 \mathrm{ml}$ respectively (Fig. 13, Fig. 14). Indeed, FCare an indicator of a faecal pollution of key importance [20]. However, the values found generally remain lower than the values required by the Moroccan standard [13]. So surface water is classified as one of good quality.

Overall, the presence of these bacteria in the waters studied could be ascribed, in part, to contamination from faecal matter of the fauna (birds, farm animals, etc.) that are hosting and frequent this aquatic environment. Contamination is also triggered by the lateral domestic and industrial wastewater effluents along the mouth of the Loukkos River.

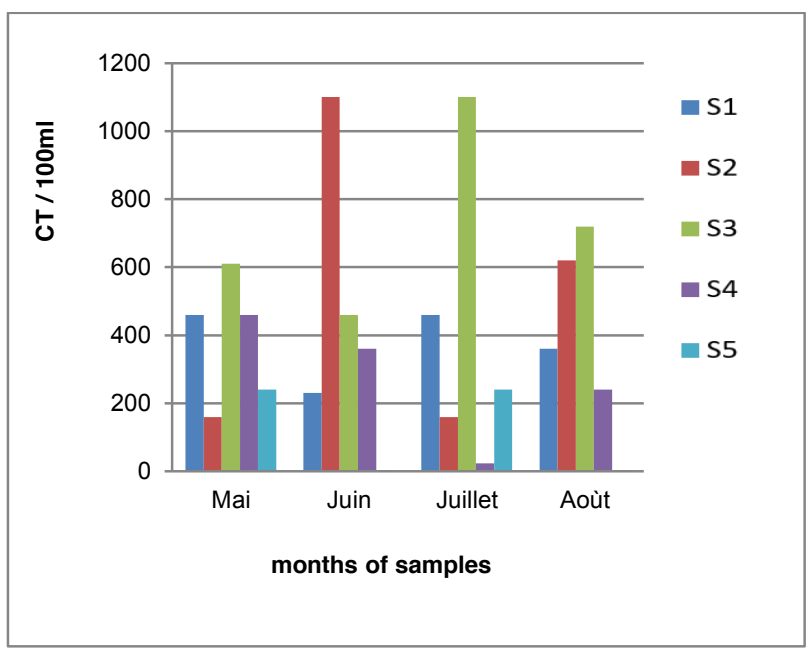

Fig. 13. Spatiotemporal evolution of total coliforms. 


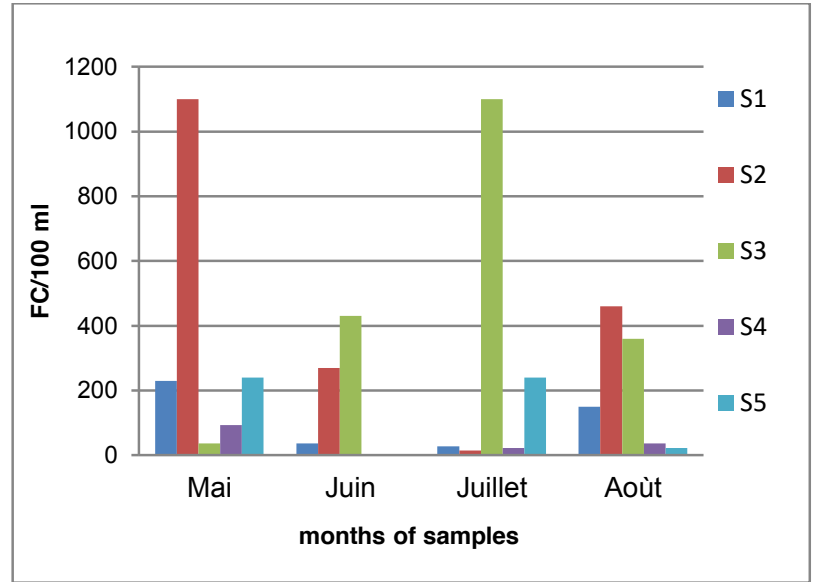

Fig. 14. Spatiotemporal evolution of faecal coliforms.

As regards the spatiotemporal evolution of intestinal enterococci, the results of the analyses showed that the low charges-were recorded during the month of May for all the sites under study. On the other hand, the highest content was observed in S3 site during the month of July with a value of $1,110^{3} \mathrm{UFC} / 100 \mathrm{ml}$ (Fig. 15). Mainly, the presence of these bacteria in the stations studied provides information about a past contamination [21], these results are lower than those found by Mehanned and al, (2014) in the waters of Oued Mikkés and Mellah in the region of Meknes [22].

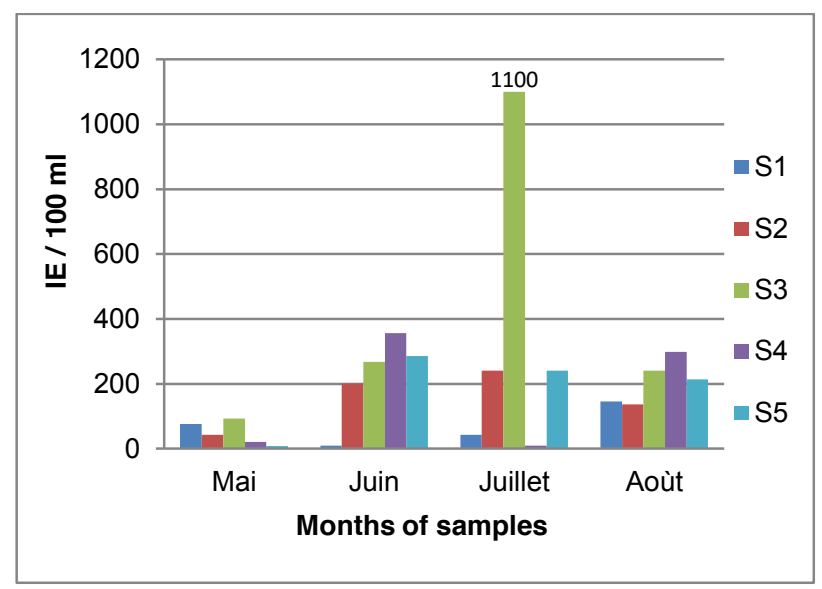

Fig. 15. Spatiotemporal evolution of intestinal enterococci.

Monitoring the evolution of anaerobic sulphitereducing bacteria in the water of the stations studied showed a very low charge during the study period.

Low levels of sulphite-reducing anaerobes in the waters of S1, S2 and S3 sites were registered with average values $3 \mathrm{UFC} / 100 \mathrm{ml}, 15 \mathrm{UFC} / 100 \mathrm{ml}$ and $6,75 \mathrm{UFC} / 100 \mathrm{ml}$ respectively. As we note the total absence of these spores on the S4 and S5 sites (Fig. 16). This could be explained by the high redox potential of the water given the shallow depth and the merging provided by the strong hydrodynamics of the ecosystem.

The water load ratio of faecal coliforms to that of intestinal enterococci at the five sites during the study period provides information on the origin of the contamination. [23].

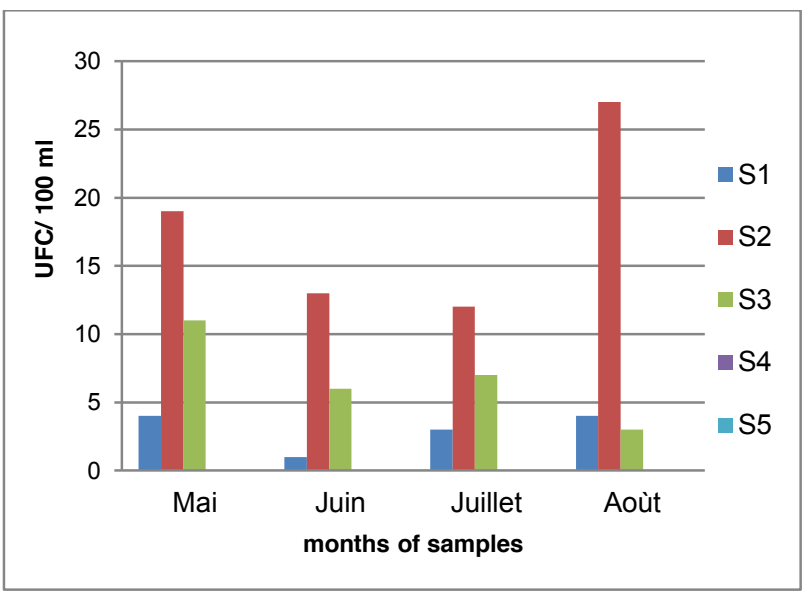

Fig. 16. Spatiotemporal evolution of sulphite-reducing anaerobes.

Table 3. Spatiotemporal evolution of the ratio of faecal coliforms (FC) to intestinal enterococci (IE) during the study period and origin of the contamination.

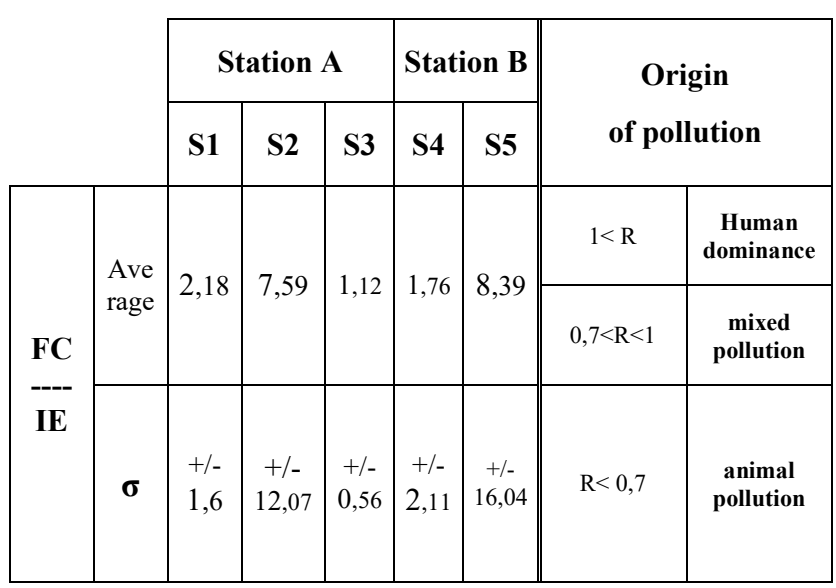

These results showed that:

In station $\mathrm{A}$ : for $\mathrm{S} 1$ and $\mathrm{S} 2$ sites the contamination appears to be of human origin. This leads us to estimate that the origin of contamination is animal especially in May for the site S3.

In station B: in general, contamination is more human than animal in S4 and S5 sites during the study period, with, but this pollution becoming more of animal origine in the month of July, a period when grazing conditions are more favourable.

\section{Conclusion}

Physicochemical analyses show that the water of the lower Loukkos complex is generally meets the standards of the surface water quality grid [24] for all the parameters studied, wich is favourable for the development of aquatic life, except that nitrate levels fluctuate downstream of the rice fields in this wetland. The spacialisation of the results made it possible to highlight the interactions between the different physicochemical phenomena. Bacteriological analyses show the presence of germs that are indicative of water pollution in the wetland but remain sum in compliance both with surface water standards during the 
period of the study and with the results obtained by studies in 2009 on this estuary [9]. The good quality of this water was detected even with the presence of a significant flow of liquid discharges from agricultural drainage and discharges from agro-industrial units in the industrial zone installed in this aquatic ecosystem. The origin of contamination is the leaching of contaminates from agricultural lands by the Loukkos River,. These liquid agro-industrial discharges together with the livestock and grazing activities centred on its meadows. The lower Loukkos complex seems yet to be able to play one of these biogeochemical purification functions ensuring the maintenance of biodiversity in this ecosystem. This work has shown that the quality of surface water is within standards,. However, the vulnerability of this wetland to pollution by wastewater remains worrying, It is recommended that studies be carried out in more depth on three main areas: on the influence of the spatial evolution of this Ramsar site on the quality of the water, on the techniques and methods of installing suitable treatment for liquid effluents from industrial units in the region, and finally on the establishment of a domestic water sanitation network for the riparian Douars to maintain its balance.

\section{References}

1. E. Maltby, T. Barker, The Wetlands Handbook, 13 (2009)

2. P.W. Leadley, C.B. Krug. R. Alkemade, Progress towards the aichi biodiversity targets: An assessment of biodiversity trends, policy scenarios, and key actions, (2014)

3. WWF, Living Planet: Species and spaces, people and places. Gland, Switzerland. (2014)

4. H. Bou Saab, N. Nassif, A G. El Samrani, R. Daoud, S. Medawar, N. Ouaïni, Survey of bacteriological surface water quality (Nahr Ibrahin River, Lebanon),

5. S. Errochdi, M. El Alami, N. Bennas, B. Belqat, M. Ater and F. Fdil, Study of physicochemical and microbiological quality of two north Moroccan hydrographic networks: Laou and Tahaddart, (2009)

6. C. Beltrame, C. Perennou, A. Guelmami, Évolution de l'occupation du sol dans les zones humides littorales du Bassin méditerranéen de 1975 à 2005, (2015)

7. M. Dakki, FDR, 2 (2002).

8. FAO, Littoral, Activités humaines et stratégie de développement durable : Cas du Maroc, 12 (2014)

9. M. Elmorhit, Hydrochimie, éléments traces métalliques et indices écotoxicologiques sur les différentes composantes d'un écosystème estuarien bas loukkos, (2009)

10. A. Aminot, R. kerouel, Hydrologie des écosystèmes marins : paramètres et analyses, 65 (2004)

11. IBGE, Qualité physico-chimique et chimique des eaux de surface, 2 (2005)
12. N. Iounes, M. Chlaida, M. Kabriti, A. S. 256270 (2016)

13. MUAT, Grille de qualité des eaux de surface (2002)

14. M. Bertrand, Le Portrait de l'environnement $d u$ Centre-du-Québec. 8 (2001)

15. L. Klein. River pollution, J. S. 6 (1973)

16. C. Mignot, Etude des propriétés physiques de différents sédiments très fins et de leur comportement sous des actions hydrodynamiques. 5 (1968).

17. E. Derwich, Z. Beziane, L. Benaabidate, D. Belghyti, J L, 77 (2008)

18. S. El Blidi, M. FEKHAOUI, Hydrologie et dynamique marégraphique de l'estuaire du Sebou (Gharb, Maroc), 61 (1995)

19. K.J.F. Verhoeven, J.L. Jannink. L.M. McIntyre. Heredity, 96 (2006)

20. M. René, L'eau, sa pollution, et son traitement, 13 (2010)

21. W.H. O, Guidelines for drinking water quality 1, 8 (1993)

22. S. Mehanned, A. Chahlaoui, A. Zaid. M. Chahboune, A. Dehbi. IOSRJEN, 4, 6 (2014)

23. M. Patoine, SE, 24, 4 (2011)

24. S. E. E. E, Surface water quality grid 1, 3 (2002) 